\title{
The Leadership of Principal in Improving Elementary Teacher Performance in Bungong Keupula Classes Ulee Kareng Banda Aceh City Indonesia
}

\author{
Lizhi Chijri \\ SD Gugus Bungong Keupula \\ Banda Aceh, Indonesia \\ lizhichijri12@gmail.com
}

\author{
Murniati \\ Department of Educational Administration \\ Universitas Syiah Kuala, Indonesia \\ lizhichijri12@gmail.com
}

\author{
Nasir \\ Department of Educational Administration \\ Universitas Syiah Kuala, Indonesia \\ lizhichijri12@gmail.com
}

\begin{abstract}
Leadership is the process of someone influencing, managing, directing, and moving individuals or groups of people by giving examples to do a goal to be achieved. The purpose of this study was to determine the principal's policy, the principal's strategy, and the principal's constraints. This study uses a qualitative approach with descriptive methods. Data collection techniques are carried out by interviews, observation, and documentation studies. Subjects in this study were principals, curriculum officers, and teachers. The results of the study show that: (1) the policies of the principal in improving teacher performance are formulating the vision, mission, and objectives of the school, compiling the RKS and RKAS, and holding various other work programs to improve teacher performance; (2) the principal's strategy is to actively involve himself and the teacher in various educational events in the form of education and training for teachers, education seminars, workshops, comparative studies, and special guidance for students who excel; (3) one of the obstacles in improving teacher performance is the lack of understanding of teachers in striving for their performance to continue to increase. This lack of understanding which is part of the lack of care for its performance so far, this will have an impact on the teacher's performance whether it is increasing or even decreasing.
\end{abstract}

Keywords: leadership, principal and teacher's performance

\section{INTRODUCTION}

The success of a school in improving student achievement is strongly influenced by the ability of the principal in leading his subordinates, especially teachers. Therefore, the principal must be able to develop the knowledge and abilities of teachers in his school. The teacher's professional behavior and ability in the education process will give influence and color to the students' behavior, personality, intellectual development. In the whole process of education and learning the teacher holds the most important role. The teacher as an important component in an educational institution, is required to have the potential in his profession as a teacher, then he must also be able to convey all his knowledge and abilities in the form of education and learning, so that the results of both can be seen and felt by students.

Teacher performance is a way for an educator to exercise influence for others and can be recognized by others. Ability gained both cognitive, affective, and psychomotor aspects that must be utilized by the results in solving problems that occur in everyday life, the ability of teacher performance can be judged from the way of thinking, acting, and understanding a problem. The performance or work of a teacher in relation to his duties as an educator can be identified in the form of commitment, discipline and responsibility in carrying out the learning process. As for the principal to be able to carry out the leader's role is required to have competence in accordance with the Ministry of National Education Decree No. 13 / 2007 namely: ( 1) personality competence; (2) managerial;
(3) entrepreneurship; (4) supervision; and (5) social competence.

In terms of their responsibilities, the principal is clearly higher and the problem complex is compared to other education personnel at the school level. Therefore, the good and bad of an educational institution will be largely determined by the extent to which the principal in one unit and one level of education is able to move all available educational components with the leadership capital they have. The more he is able to dynamize the teacher, the greater the chance of him becoming a leader who can manage educational institutions professionally.

Principal leadership can have a significant impact on the success of teacher performance under his leadership. This often happens in the process of improving teacher performance in schools. The reality as stated above often causes problems or obstacles for school principals in the aim of improving teacher performance, this needs to be examined and a solution is sought so that it is not sustainable so that in trying to improve teacher performance there are obstacles that affect the quality of learning and improve the quality of education. then the authors are interested in conducting a comprehensive study in the form of Title: Principal Leadership in Improving the Performance of Elementary Teachers in Gugus Bungong keupula Kec. Ulee Kareng Banda Aceh City.

\section{METHODS}

This study uses descriptive methods, qualitative approaches, data collection techniques: 
observation, interviews, and documentation. Research subjects: Principal, Deputy Curriculum, and Elementary Teacher. Data analysis techniques for qualitative analysis. The time for conducting the research lasted for three months starting on May 14 s.d July 26 2018. In accordance with the form of qualitative research approaches and data sources used, the data collection techniques used were document analysis, observation and interviews.

\section{RESULT AND DISCUSSION}

From extracting data, there are several things that can be described, namely:

\section{Principal Policy}

As a leader the principal has a role that is so influential in the development and progress of the school. School development and progress can be seen from the performance of professional principals in utilizing available resources. The principal must be able to utilize it effectively and efficiently. Seeing the roles and duties of the various principals, principals are faced with the challenge of implementing a planned and organized education and continuously developing the quality of education. The principal can do this by having a clear and directed vision. This can be seen from the policy of the principal at SDN 56, namely by the rules and programs made, among others; RKS; vision, mission and goals; and various other programs. The effort was carried out by the principal with the aim of developing the quality of education through program implementation activities in schools.

A leader must be shown by behavior that is able to encourage and provide positive motivation so that all subordinates involved can influence the example of his leadership. Karwati and Priansa (2016: 194) stated that: principals have an obligation to make teachers, staff, and other employees able to act by providing examples for further growth. Exemplary contributions contribute significantly to followers' behavior. So with other things, the behavior shown indirectly by a school principal can affect the teacher's performance in a good direction or even the opposite.

The performance of a teacher will appear in everyday working conditions and conditions. In classroom learning, the teacher is very influential for students in receiving the material. According to Surya (Kunandar 2009) professional teachers will be reflected in the implementation of dedication tasks marked by expertise in both material and methods. The conditions in the field at SDN 56 have led to the goal of education through the leadership of school principals who can provide motivation and encouragement by showing a sense of friendship, closeness and full consideration of the teachers, both as individuals and as a group. This ability should be owned by everyone who leads. Mulyasa (2013) states that: the principal should not be held by a weak person, especially in making decisions, determining policies, or someone who is principally the principle.

On the contrary, the conditions in the field at SDN 11 were not in line with expectations. In fact many teachers feel that their profession is a burden so that their responsibilities as educators and teachers are not carried out with pleasure. Tanlain, et al. (Sagala, 2013) mentions the points that are the responsibility of the teacher, among others: "Obeying human norms and values, accepting the task of educating not as a burden, but with joy and pleasure, aware of what is done and the consequences of each act. , learning and teaching rewards others, including students, being wise and careful and careful, and as religious people do all that is above taqwa to God Almighty.

The task and role of the principal must be balanced with a strong, firm, and strong character and personality in all policies that he will carry out so that it can be used as an example for all who are under his supervision as a leader. Kompri (2015) states that: showing yourself as a strong or strong person. The way people see, act and speak will influence the views of others to see them as strong or helpless. Leaders who stand upright and calm, firmly clear and neat can present a picture of good personal control and power. So, as a leader in a formal institution, especially an educational institution, namely a school, a leader has a very large role as someone who manages, supervises, directs, fosters and moves into various improvements and developments in all programs and policies planned to achieve a result as desired.

\section{Principal Strategy}

The principal is the implementer of a close task in the hope of change and renewal. To carry out the task and realize that expectation, a school principal must pay attention to the rules and guidelines that he will produce into a strategy. The strategy will bring the institution he leads to a better direction, and the school principal is expected to be a diligent and orderly implementer as well as an example for teachers to make schools a quality institution. This statement is in accordance with the leadership of the principal at SDN 56 which leads to an example school / as a core school. Mulyasa (2013) states that: there are indicators of effective leadership of principals as follows; ... showing exemplary attitudes and behaviors that can be role models or models for teachers, students and all school citizens. Thus, a good and effective leader in his role as a leader, he will be able to carry out his leadership strategy well to produce and bring about a change towards a better direction.

Wahyudi (2012) states that: there are several efforts that can be done by the principal to improve teacher performance, as explained in the following description:

1. Establishing cooperative relationships with teachers. The establishment of a good cooperative relationship between the principal and the teacher, the school objectives can be achieved easily.

2. Establish communication with the teacher. Communication is very important to be done by the principal so that the school program can be understood well by the teacher.

3. Provide guidance and assistance in completing teacher assignments. The school principal provides guidance and assistance in an effort to facilitate the implementation of teacher duties in the learning process at school. 
4. Building teacher morale / morale. For teachers who have not succeeded in completing the task, it is the duty of the principal to foster selfconfidence for the teacher to succeed in completing the task.

5. Giving awards to outstanding teachers. The award given by the principal in recognition of the achievements of the teacher with his maximum effort so as to maintain and improve his achievements.

6. Resolve all problems at school. School as an institution cannot be separated from various problems, so that the problem does not drag on and become more complex, then the principal immediately identifies the problem and then resolves it.

7. Include teachers in formulating decision making. The teacher is the implementer of every decision in school, so that decisions can be accepted by all parties, then the teacher must be involved in decision making.

8. Resolve conflicts in school. Conflicts that conflict with school objectives should be avoided, but the existence of conflict cannot be avoided, so the task of the headmaster is to manage conflict properly.

9. Respect school regulations. Not only teachers, employees and students who must obey school rules, but principals must also respect school rules.

10. Creating a competitive climate / healthy working climate among teachers. All teachers want to get promotions, salary increases or other awards, so the principal creates a fair atmosphere in giving awards.

The efforts made by the school principal are the principals carrying out leadership well, namely by conducting coaching, guiding and directing teachers to be more qualified. In addition, the principal also provides motivation, socializes well to all elements involved, and manages the school well to achieve the expected goals. Wahyudi (2012) argued the principal continuously provides support so that teachers are accustomed to doing the tasks correctly and training teachers to provide suggestions on organizational policy.

The implementation of the principal strategy of SDN 11 still needs to be improved again in the direction of the task and the provision of motivation to each teacher, so that they can achieve more teacher competencies. According to Rusman (2013), teacher competence, namely the ability of a teacher to carry out his responsibilities responsibly and properly. Furthermore, Wahyudi (2012) stated principals must open themselves to the implementation of a constructive dialogue and actively pay attention to efforts that support the ability of teachers.

\section{Principal Barriers}

Every educational institution / organization led by a leader certainly has obstacles or constraints in its implementation. For a leader, employee performance is the key to victory that must be achieved from the way of leadership. Therefore, a leader must be careful and wise in carrying out his professionalism as a leader who can influence the performance of employees in the direction they want to achieve. obstacles or problems that arise from the work program, academic, staffing, and students. The obstacles that arise are the tasks and roles that must be completed by a leader. In line with this presentation, Basri (2014) stated that: problem solving is a complex take in choosing alternatives that can overcome obstacles and obstacles that affect the goal of achieving goals.

The obstacles that are often encountered in the world of education are the lack of a sense of professionalism and a sense of responsibility of a teacher as a teaching force in the school. Kunandar (Priansa, 2014) states that: professionalism is a condition, direction, value, purpose, and quality of a skill, and authority related to one's livelihood. a professional teacher is able to understand his duties and responsibilities as an employee and teaching staff in the school. The task of the teaching staff in addition to providing good learning at school is to improve their professionalism as a teacher and educator. In addition to the professionalism of a person, the teacher's performance will become more optimal if integrated with the school's components, both principals, school climate, teachers, employees and students.

\section{CONCLUSION}

Efforts made by 56 elementary school principals in the city of Banda Aceh can be seen from several things, namely: (1) involving teachers in training; (2) provide facilities needed by teachers and students in the learning process, one of them is a book for students; (3) the principal is firm in giving directions and monitoring the teacher when learning takes place periodically around looking at the class; (4) give reprimands to teachers who are less disciplined; (5) the principal applies open / transparent management; and (6) the principal treats the teacher as a work partner not as a person who is employed. The efforts made by the principal in school are more effective because the teacher is better through his firmness as a leader, orderly and disciplined in carrying out his duties well starting from planning, implementing to evaluating / evaluating learning.

The efforts made by the principal in improving teacher performance at school can be seen from several things, namely: (1) include teachers in various training both inside and outside the school; (2) judging from the physical condition of the school (environment) there are still many things that can be further developed for example, applying a beautiful environment both from the planting of flowers and trees, and not strictly in the responsibility of the teacher towards the classroom learning tools; (3) the principal is not assertive in taking a stand for teachers who violate school rules / rules, for example discipline; (4) the attitude of the school principal is transparent with all educators and education staff; and (5) there are no 
sanctions imposed by principals for teachers who violate school regulations.

\section{REFERENCES}

[1] Basri, H. 2014. Kepemimpinan Kepala Sekolah. Bandung: CV Pustaka Setia.

[2] Kopri. 2015. Manajemen Pendidikan. Bandung: Alfabeta.

[3] Priansa, D. J. 2014. Kinerja dan Profesionalisme Guru. Bandung: Alfabeta.

[4] Muslich, M. 2009. KTSP Pembelajaran Berbasis Kompetensi dan Kontekstual. Jakarta: PT Bumi Aksara.

[5] Mulyasa. 2013. Manajemen \& Kepemimpinan Kepala Sekolah. Jakarta: PT Bumi Aksara.

[6] Karwati, E., \& Priansa, D. J. 2016. Kinerja dan Profesionalisme Kepala Sekolah. Bandung: Alfabeta.

[7] Kunandar. 2009. Guru Profesional: Implementasi Kurikulum Tingkat Satuan Pendidikan (KTSP), dan Sukses dalam Sertifikasi Guru. Jakarta: Rajawali Pers.

[8] Rusman. 2013. Model-model Pembelajaran: Mengembangkan Profesionalisme Guru. Jakarta: Rajawali Press.

[9] Sagala, S. 2013. Kemampuan Profesional Guru dan Tenaga Kependidikan. Bandung: Alfabeta.

[10] Wahyudi. 2012. Kepemimpinan Kepala Sekolah dalam Organisasi Pembelajaran. Bandung: Alfabeta. 